\title{
Fruit rot on olive caused by Pilidium concavum in Iran
}

\author{
Mahdi Arzanlou • Mohsen Torbati • Hossein Jafary
}

Received: 25 March 2013 / Accepted: 11 July 2013 /Published online: 11 August 2013

(C) Australasian Plant Pathology Society Inc. 2013

\begin{abstract}
A new fruit rot disease was observed on olive fruits (Olea europaea L.) in the orchards of the Tarom region (Zanjan province, Northwest Iran). The symptoms of the disease appeared as water-soaked lesions on fruits, later becoming brownish and coalescing, which resulted in rotten and mummified fruits. Isolation was made from symptomatic tissues. The causal agent of the disease was identified as Pilidium concavum based on morphological and cultural characteristics. The identity of the species was further confirmed using sequence data from ITS-rDNA region. The ITS sequence generated in this study showed $100 \%$ homology with the sequence data for $P$. concavum from GenBank. Koch's postulates were fulfilled by inoculation of surfacesterilized fresh olive fruits under laboratory conditions using a spore suspension. This is the first report of the occurrence and pathogenicity of $P$. concavum on olive fruits anywhere in the world.
\end{abstract}

Keywords Olea europaea · Mummified fruits · Leotiomycetes $\cdot$ Coelomycete

Olive (Olea europaea L.), is an important oil-producing crop in Mediterranean countries such as Spain, Italy, Greece, Turkey, and many other countries such as USA (California), Argentina, Chile, Australia and New Zealand (Zohary and Hopf 1994; Noormohammadi et al. 2007). Iran has a long history with olive

\footnotetext{
M. Arzanlou $(\triangle) \cdot$ M. Torbati

Plant Protection Department, Faculty of Agriculture, University of Tabriz, P.O. Box 5166614766, Tabriz, Iran e-mail: arzanlou@hotmail.com

M. Arzanlou

e-mail: Arzanlou@tabrizu.ac.ir

H. Jafary

Agricultural and Natural Resources Research Center of Zanjan Province, Zanjan, IranPO Box: 45195-1474
}

cultivation and there is ample evidence that regions near the Caspian Sea in northern Iran are a presumed center of origin for olive (Noormohammadi et al. 2007). The Iranian olive industry is a relatively small farming business distributed mainly in the north of the country, covering a total area of over 80,000 ha (Sadeghi 2002; Noormohammadi et al. 2007; Arzanlou et al. 2012). In recent years, there is growing interest by government and local authorities in establishing new olive orchards in different provinces of the country; thus current trends are for acreage increase and planting new varieties in different parts of the country (Noormohammadi et al. 2007). The olive plants are susceptible to numerous debilitating diseases which limit olive production in many olive-producing countries and also in Iran (Lazzizera et al. 2008; Moral et al. 2009). Fungal diseases cause significant economic losses to the olive industry through yield loss, reduction in growth, and increase in production costs (Lazzizera et al. 2008; Moral et al. 2009). Several fungal diseases such as Verticillium vascular wilt, peacock eyespot and fruit rot diseases have been reported on olive in Iran (Ershad 2009; Arzanlou et al. 2012). Various kinds of fruit rot are widespread on olive in many olive-producing countries, reducing the quality and quantity of the product through direct loss of rotten fruits, reduced commercial value of table olives and reduced quality of the oil due to fungal infections (Lazzizera et al. 2008). Diverse fungal groups have been reported to cause fruit rot on olive, including species of Botryosphaeriaceae such as Botryosphaeria, Diplodia, Lasiodiplodia, Macrophomina, Neofusicoccum and Camarosporium; Glomerellaceae including Colletotrichum; Mycosphaerellaceae incl. Pseudocercospora and several other fungal species with minor importance such as Fusicladium oleagineum, Alternaria spp., Aureobasidium pullulans, Epicoccum nigrum, Cladosporium herbarum s.l., Capnodium elaeophilum and Truncatella angustata (Avila et al. 2005; Athar 2005; Chattaoui et al. 2011; Moral et al. 2008, 2009; Sergeeva et al. 2009; Arzanlou et al. 2012). In the present study we report a new fruit rot fungal disease on olive in Iran. 
In a survey on fungal agents involved in olive fruit rot in orchards of the Tarom region in the Zanjan province, fruits with rot symptoms were collected from olive orchards in four counties. In total eight orchard and seven trees per orchard were inspected. The incidence of the fruit rot was $2.4 \%$. Disease symptoms of fruit rot started as small, brown, watersoaked spots, increased in diameter and became wrinkled with age. The mummified fruits remained attached on the tree (Fig. 1). Isolations were made from diseased tissues by cutting small pieces from the margin of the lesions, the tissues were then surface-sterilized for 15-20 s in 70\% ethanol, rinsed with sterile water three times, dried on sterile filter paper and transferred to Potato Dextrose Agar (PDA, Fluka, Hamburg, Germany) plates supplemented with $100 \mathrm{mg} \mathrm{L}^{-1}$ of streptomycin sulphate. Single-spore cultures were established from sporulating colonies as described by Bakhshi et al. (2011). Briefly, under a stereomicroscope, with the tip of a wetted sterile inoculation needle a conidial mass on a conidioma was touched and the conidia suspended on PDA plates (supplemented with streptomycin sulfate $\left(100 \mathrm{mg} \mathrm{L}^{-1}\right)$ ), containing $10 \mathrm{ml}$ sterile water. The suspension was evenly spread on the agar surface and plates were kept in oblique position overnight. The plates then were checked under the stereomicroscope and germinated conidia were transferred to new PDA plates. Single-spore cultures are preserved on PDA in $2 \mathrm{ml}$ microtube slants at $4{ }^{\circ} \mathrm{C}$ in the Culture Collection of Tabriz University and Iranian Fungal Culture Collection with

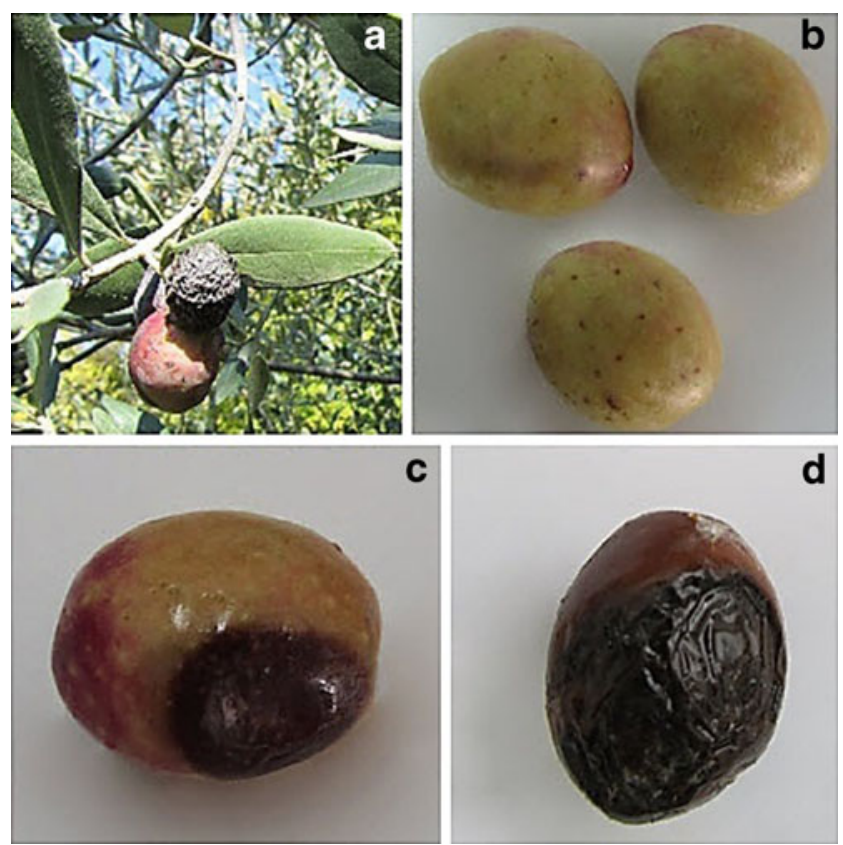

Fig. 1 Disease symptoms and pathogenicity assay. a Symptomatic fruits of Olea europaea naturally infected with Pilidium concavum. b Control (uninoculated) fruits of cultivar Zard without symptoms. c-d Symptoms developed on in vitro inoculated olive fruits, 7 and 14 days after inoculation, respectively accession numbers CCTU $1200=$ IRAN $2183 \mathrm{C}$ and CCTU $12001=$ IRAN 2182C, respectively.

Cultural, including colony color, shape and growth rate and microscopic features were studied on Potato Dextrose Agar (PDA), Malt Extract Agar (MEA) and Oatmeal Agar (OA) culture media after 7 days of incubation on $25^{\circ} \mathrm{C}$ under alternating fluorescent $(12 \mathrm{~h})$ and near ultraviolet $(12 \mathrm{~h})$ light. Microscopic characters were studied using a smash mount technique with sterile distilled water as described by Arzanlou et al. (2007). Morphology and size of microscopic structures were assessed based on 30 measurements. In culture, the mycelia were hyaline to pale brown, with septate, branched; 2-4 $\mu \mathrm{m}$ wide hyphae. The sporodochia, (275-) 280-300 $(-350) \times(70-) 82-119(-130) \mu \mathrm{m}$, were scattered, sessile, relatively spherical, thick-walled, initially light colored, turning brownish or almost black in older cultures. Conidiophores forming a dense palisade, hyaline to pale brown, tapering distally, (12-) 23-31 (-40)×(1-) 1.8-2.3 $(-3) \mu \mathrm{m}$. Conidiogenous cells phialidic, hyaline, tapering towards the apex. Conidia 1-celled, hyaline, fusiform to slightly falcate, apex acute, base obtuse, thin-walled, formed singly on the conidiogenous cells, (3-) 5-6 (-8) ×(1-) 1.4 $1.7(-2) \mu \mathrm{m}$.

The colony diameter was assessed based on three replicates. On MEA colonies reaching $29 \mathrm{~mm}$ diam in 7 day, initially white, turning brown in center with the production of conidiomata, felted, with sparse aerial mycelium. On PDA colonies reaching $37 \mathrm{~mm}$ diam in 7 day, white, with sparse aerial mycelium. On OA colonies reaching $44 \mathrm{~mm}$ diam in 7 day, initially white, turning brown in the center with production of conidiomata (Fig. 2). The identity of the causal agent was further confirmed using sequence data from ITSrDNA region. For this purpose, DNA was extracted from 7day-old cultures grown on PDA, using the protocol of Moller et al. (1992). The primers V9G (de Hoog and Gerrits van den Ende 1998) and LR5 (Vilgalys and Hester 1990) were used to amplify the $3^{\prime}$ end of the 18S rRNA gene, ITS1, 5.8S rDNA, ITS2 and the first approximately $900 \mathrm{bp}$ of the $5^{\prime}$ end of the 28S nrRNA gene. PCR was performed on a GeneAmp PCR System 9700 (Applied Biosystems, Foster City, CA). The reaction mixture contained $1 \times$ PCR buffer, $1 \mathrm{mM}$ $\mathrm{MgCl}_{2}, 60 \mu \mathrm{l}$ of $1 \mathrm{mM}$ dNTPs, $0.2 \mathrm{pM}$ of each primer, $0.5 \mathrm{U}$ of Taq polymerase, $0.5 \mu \mathrm{DMSO}$, and $10-15 \mathrm{ng}$ of fungal genomic DNA. The final reaction volume was adjusted to $12.5 \mu \mathrm{l}$ by adding sterile distilled water. The thermal cycling condition consisted of an initial denaturation at $95^{\circ} \mathrm{C}$ for $5 \mathrm{~min}$, followed by 40 cycles of $30 \mathrm{~s}$ at $94{ }^{\circ} \mathrm{C}, 30 \mathrm{~s}$ at $52^{\circ} \mathrm{C}$ and $1 \mathrm{~min}$ at $72{ }^{\circ} \mathrm{C}$, followed by a final extension cycle at $72{ }^{\circ} \mathrm{C}$ for $7 \mathrm{~min}$. The amplicon was sequenced using PCR primers and two additional internal primers, ITS4 (White et al. 1990) and LR0R (Rehner and Samuels 1994) in order to obtain good quality sequence over the entire length of the amplicon, by using a BigDye Terminator Cycle Sequencing 
Fig. 2 Cultural and morphological characteristics of Pilidium concavum. a-c Seven day-old colonies on MEA, PDA and OA. d Unfledged (immature) conidiomata on OA after 7 days. e Mature conidiomata on OA after 7 days. $\mathbf{f}-\mathbf{h}$ Conidiophores and conidiogenous cells on OA. $\mathbf{i}$ Conidia on OA. Bars $(\mathbf{d}-\mathbf{e})=$ $100 \mu \mathrm{m},(\mathbf{f}-\mathbf{i})=10 \mu \mathrm{m}$


Kit v. 3.1 (Applied Biosystems, Foster City, CA) and analysed on an ABI Prism 3700 (Applied Biosystems, Foster City, CA). The sequence for the ITS region was subjected to a Megablast search at NCBI's GenBank nucleotide database and sequences with high similarity were downloaded from GenBank and aligned together with the sequence obtained in this study. Sequence alignment was carried out by using the ClustalW algorithm implemented in MEGA 5 (Tamura et al. 2011).
Phylogenetic analysis was performed using maximum likelihood method with program default settings in MEGA 5. Bootstrap analysis was performed with 1,000 replicates. The phylogenetic tree was rooted to Chaetomella raphigera (GenBank accession number AY487085.1). The sequence was deposited in GenBank and the alignments in TreeBASE (www.treebase.org).

Koch's postulates were performed on surface-sterilized healthy fruits of Cultivar "Zard" as follow described.
Fig. 3 A maximum likelihood phylogenetic tree obtained for the ITS regions and 5.8S rDNA sequences. Bootstrap support values from 1,000 replicates are indicated at the nodes. The tree was rooted to Chaetomella raphigera. The scale bar indicates 0.02 substitutions per site

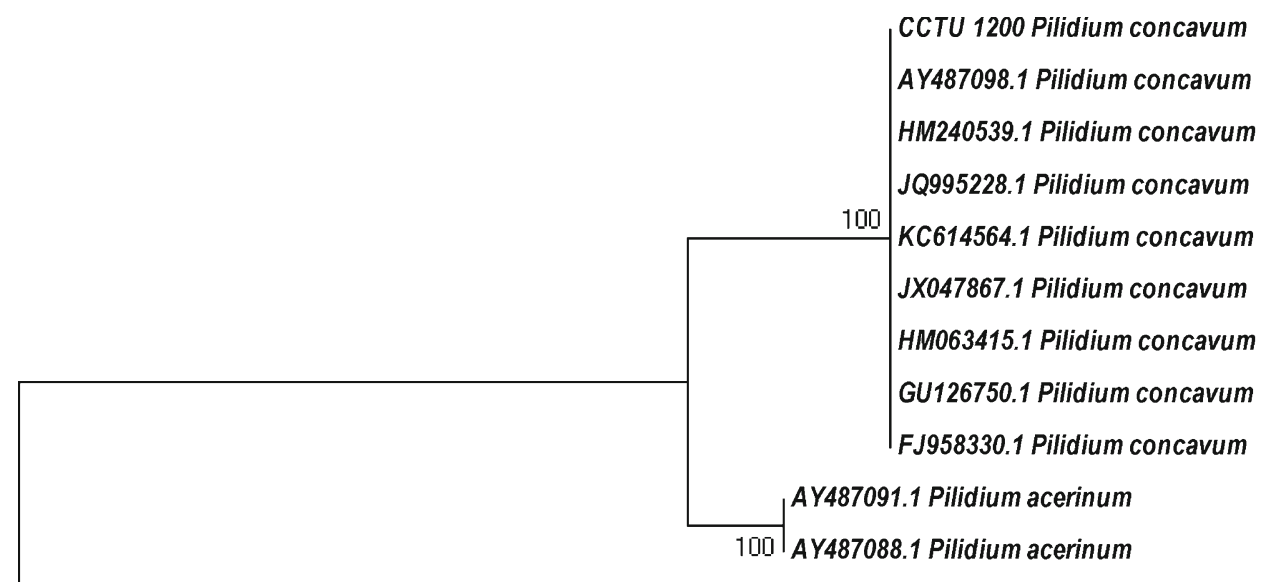

AY487085.1 Chaetomella raphigera 
Single-spore cultures were grown on PDA plates for a week to sporulate abundantly; spore suspension with a final concentration of $1 \times 10^{7}$ conidia per $\mathrm{ml}$ distilled water was prepared. Healthy mature green olive fruits were dipped in $70 \%$ ethanol for 20-30 s and rinsed three times in sterilized water. Fruits were then dipped in the spore suspension and placed in Petri dishes on sterile filter paper. The filter paper was kept wet during the experiment. For the controls, fruits were dipped in sterilized distilled water. The experiment was carried out by using two fungal isolates and ten fruits for each the fungal isolates (5 Petri dishes, each containing two fruits). Petri dishes were maintained on the lab bench at $22 \pm 2{ }^{\circ} \mathrm{C}$, for 14 days.

The morphological characteristics are in full agreement with the description of $P$. concavum (Desm.) $\mathrm{H} \mathrm{hn}$. (synanamorph Hainesia lythri (Desm.) H hn.; teleomorph Discohainesia oenotherae (Cooke and Ellis) Nannf.) (Sutton 1980; Rossman et al. 2004; Lopes et al. 2010; Geng et al. 2012), and its identify was further corroborated by phylogenetic comparison of the ITS-rDNA region of isolate CCTU 1200 with other sequences of Pilidium from GenBank which showed $100 \%$ homology with Pilidium concavum isolates from strawberry and other plant species (Fig. 3). The sequence is available in GenBank with GenBank Accession No. KF255414. The pathogenicity assay showed that Pilidium concavum was pathogenic to olive fruits. The disease symptoms appeared as brown sunken lesions after 7 days and wrinkle of fruits after 14 days, which then expanded to other parts of the fruit. Fruits in the control set remained free of blemish (Fig. 1). The original fungus was re-isolated from inoculated fruits showing the symptoms and no fungal growth was observed in the controls.

Even though there are several names published in this the coelomycetous genus Pilidium, only two species, the type $P$. acerinum and $P$. concavum are currently accepted (Rossman et al. 2004; Kirk et al. 2008). Members of this genus have phylogenetic affinity with Leotiomycetes (Rossman et al. 2004; Kirk et al. 2008). A teleomorph connection has been established for $P$. concavum in Discohainesia Nannf. in the family Dermateaceae, order Helotiales, while P. acerinum is only known the anamorph (Rossman et al. 2004). Pilidium species often produce two types of conidiomata: black pycnidia, the most commonly encountered in nature, and also sporodochia, commonly seen in pure cultures (Palm 1991; Rossman et al. 2004). The two conidiomatal types of P. concavum had been considered as two distinct species. Palm (1991) determined that the light-colored sporodochia of Hainesia lythri just represent another form of $P$. concavum. Which of the three names available for this fungus will persist, has not yet been established. In the present study only the sporodochial form was developed in pure culture; pycnidia were neither observed on naturally infected fruits nor on different culture media. Pilidium spp. are known to cause disease on crop plants and trees such as Strawberry, Eucalyptus, Elephant's ears (Bergenia crassifolia (L.) Fritsch) and Paeonia suffruticosa Andrews (Cardin et al. 2009; Duan and Kang 2010; Debode et al. 2011; Geng et al. 2012). Tan-brown leaf spot and fruit rot on strawberry caused by $P$. concavum have been reported from many countries (Opgenorth and White 1991; Golebniak and Jarosz 2004; Cardin et al. 2009; Duan and Kang 2010; Geng et al. 2012). P. acerinum has been considered as a weak pathogen on Eucalyptus in South Africa (Crous 1991). In the present study, $P$. concavum was isolated from olive orchards in the Tarom region in Zanjan province in northwestern Iran. Although P.concavum has recently been reported to cause fruit rot disease on Prunus domestica in northern Iran (Sayari et al. 2013), to the best of our knowledge, this is the first report on the occurrence of $P$. concavum on olive anywhere in the world. The disease cycle, distribution, host range and impact of the disease on crop yield remains to be studied.

Acknowledgments The authors would like to thank the Research Deputy of the University of Tabriz, for financial support. The authors are indebted to Prof. Walter Gams for his valuable comments and critical reading of the manuscript.

\section{References}

Arzanlou M, Groenewald JZ, Gams W, Braun U, Shin H-D, Crous PW (2007) Phylogenetic and morphotaxonomic revision of Ramichloridium and allied genera. Stud Mycol 58:57-93

Arzanlou M, Torbati M, Jafary H (2012) Fruit rot of olive (Olea europaea) caused by Truncatella angustata. Plant Pathol Quar 2:117-123

Athar M (2005) Infestation of olive fruit fly, Bactrocera oleae, in California and taxonomy of its host trees. Agric Conspec Sci 70:135-138

Avila A, Groenewald JZ, Trapero A, Crous PW (2005) Characterization and epitypification of Pseudocercospora cladosporioides, the causal organism of Cercospora leaf spot of olives. Mycol Res 109:881-888

Bakhshi M, Arzanlou M, Babai-Ahari A (2011) Uneven distribution of mating type alleles in Iranian populations of Cercospora beticola, the causal agent of Cercospora leaf spot disease of sugar beet. Phytopathol Mediterr 50:101-109

Cardin L, Vincenot L, Balesdent MH (2009) First report of Pilidium concavum on Bergenia crassifolia. Plant Dis 93:548p

Chattaoui M, Rhouma A, Krid S, Ali Triki M (2011) First report of fruit rot of olive caused by Botryosphaeria dothidea in Tunisia. Plant Dis 95:770-770

Crous PW (1991) Two newly reported leaf pathogens of Eucalyptus grandis in South Africa. South Afr For J 157:12-15

de Hoog GS, Gerrits van den Ende AHG (1998) Molecular diagnostics of clinical strains of filamentous Basidiomycetes. Mycoses 41:183-189

Debode J, Van Hemelrijck W, Heungens K, Maes M, Creemers P (2011) First report of Pilidium concavum causing tan-brown rot on strawberry fruit in Belgium. Plant Dis 95:1029

Duan YB, Kang B (2010) First report of Pilidium concavum on Paeonia suffruticosa in China. Plant Dis 94:271

Ershad D (2009) Fungi of Iran. 3rd edition, Iranian Research Institution of Plant Protection, 531 
Geng WL, Hu P, Ma Z, Zhao XY, Wei M (2012) First report of Pilidium concavum causing tan-brown leaf spot on strawberry in China. Plant Dis 96:1377

Golebniak B, Jarosz A (2004) First report of tan-brown rot (Hainesia lythri) on strawberry fruits in Poland. Phytopathol Pol 31:57-60

Kirk PM, Cannon PF, Minter DW, Stalpers JA (2008) Dictionary of the fungi, 10th edn. CABI Publishing, Wallingford

Lazzizera C, Frisullo S, Alves A, Phillips AJL (2008) Morphology, phylogeny and pathogenicity of Botryosphaeria and Neofusicoccum species associated with drupe rot of olives in southern Italy. Plant Pathol 57:948-956

Lopes UP, Zambolim L, Lopes UN, Pereira OL, Costa H (2010) First report of Pilidium concavum causing tan-brown rot in strawberry fruits in Brazil. New Dis Rep 21:7

Moller EM, Bahnweg G, Geiger HH (1992) A simple and efficient protocol for isolation of high molecular weight DNA from filamentous fungi, fruit bodies, and infected plant tissues. Nucleic Acids Res 20:6115-6116

Moral J, De La Rosa R, Leon L, Barranco D, Michailides TJ, Trapero A (2008) High susceptibility of olive cultivar FS-17 to Alternaria alternata in Southern Spain. Plant Dis 92:1252

Moral J, Oliveira R, Trapero A (2009) Elucidation of the disease cycle of olive anthracnose caused by Colletotrichum acutatum. Phytopathology 99:548-556

Noormohammadi Z, Hosseini-Mazinan M, Trujillo I, Rallo L (2007) Identification and classification of main Iranian olive cultivars using microsatellite markers. HortSci 42:1545-1550

Opgenorth D, White J (1991) Hainesia leaf spot on strawberry. Calif Plant Pest Dis Rep 10:27-29

Palm ME (1991) Taxonomy and morphology of the synanamorphs Pilidium concavum and Hainesia lythri (coelomycetes). Mycologia 83:787-796
Rehner SA, Samuels GJ (1994) Taxonomy and phylogeny of Gliocladium analysed from nuclear large subunit ribosomal DNA sequences. Mycol Res 98:625-634

Rossman AY, Aime MC, Farr DF, Castlebury LA, Peterson K, Leahy R (2004) The coelomycetous genera Chaetomella and Pilidium, a new discovered lineage of inoperculate discomycetes. Mycol Prog 3:275290

Sadeghi H (2002) Olive production and management. The Research, Training and Extension Organization of Agriculture, Agricultural Training Publication, Karaj, Iran, 413 pp

Sayari M, Babaeizad V, Fathi J (2013) First report of Pilidium concavum as the causative agent of tan-brown rot of Prunus domestica fruits in Iran. J Plant Pathol. doi:10.4454/JPP.V95I2.017 (in press)

Sergeeva V, Alves A, Phillips AJL (2009) Neofusicoccum luteum associated with leaf necrosis and fruit rot of olives in New South Wales, Australia. Phytopathol Mediterr 48:294-298

Sutton BC (1980) The Coelomycetes. Fungi imperfecti with pycnidia, acervuli and stromata. Commonwealth Mycological Institute, Kew, UK, 696pp

Tamura K, Nei M, Kumar S (2011) MEGA5: molecular evolutionary genetics analysis using maximum likelihood, evolutionary distance, and maximum parsimony methods. Mol Biol Evol 28:2731-2739

Vilgalys R, Hester M (1990) Rapid genetic identification and mapping of enzymatically amplified ribosomal DNA from several Cryptococcus species. J Bacteriol 172:4238-4246

White TJ, Bruns TD, Lee SB, Taylor JW (1990) Amplification and sequencing of fungal ribosomal RNA genes for phylogenetics. In: Innis N, Gelfand D, Sninsky J, White TC (eds) PCR protocols and applications - a laboratory manual. Academic, New York

Zohary D, Hopf M (1994) Domestication of plants in the Old World: the origin and spread of cultivated plants in west Asia, Europe, and the Nile Valley, 2nd edn. Clarendon, Oxford, pp 137-442 